\title{
Mild sickle-cell anaemia in Iran associated with high levels of fetal haemoglobin ${ }^{1}$
}

\author{
M. HAGHSHENASS, F. ISMAIL-BEIGI, J. B. CLEGG, AND \\ D. J. WEATHERALL
}

From the Department of Internal Medicine and Pahlavi Medical Research Institute, Pahlavi University, Shiraz, Iran; and Nuffield Department of Clinical Medicine, University of Oxford, Oxford

SUMMARY Sixteen subjects, with sickle-cell anaemia, all Iranians (ages 3 to 56 years), with very mil symptomatology are reported. Some of the subjects had been totally asymptomatic. Splenomegaly was noted in 9 cases. There was an increase in the mean level of fetal haemoglobin $(18 \%)$; this is th: probable explanation for the mild phenotype. In 29 subjects with sickle-cell trait, the level of $\mathrm{Hb} \mathrm{F}$ was also significantly raised as compared with normal $(1.6 \%$ vs. $0.6 \%)$. The mechanism of increased synthesis of $\mathrm{Hb} \mathrm{F}$ is unknown. The findings are similar to those reported in the Shiite Moslems of Saudi Arabia suggesting that in these populations there is a genetically-determined ability to produce्ठ high levels of $\mathrm{Hb} \mathrm{F}$ in the presence of the sickle-cell gene.

Sickle-cell anaemia is usually a severe disease characterized by haemolytic anaemia, repeated painful 'crises', widespread organ involvement, and dysfunction leading to shortened survival (Coming, 1972). However, there are exceptions and some patients with sickle-cell anaemia survive to late adult life (Charache, 1964). In the past few years, several reports have appeared describing a 'benign' variant of sickle-cell anaemia (Serjeant $e t$ al., 1968; Ali, 1970; Perrine et al., 1972). The clinically mild disease was related to the relatively higher levels of fetal haemoglobin found to be present in these subjects (Ali, 1970; Perrine et al., 1972) as compared with sickle-cell anaemia of Black populations (Coming, 1972).

In this article we report the results of clinical and haematological studies on a group of 16 subjects from southern Iran with clinically mild sickle-cell anaemia many of whom have been almost completely symptom free.

\section{Subjects and methods}

The subjects were all Iranians mostly from the southern part of Iran in the Persian Gulf area. Sixteen subjects with homozygous sickle-cell anaemia

1Supported by grants from the Iran Foundation, Ministry of Higher Education No. 423-102-423-1-53 and Pahlavi University Research Council No. 51-MD-36.

Received for publication 29 October 1976 from 12 families, and 29 subjects heterozygous fop the sickle-cell anaemia (trait) were studied. Family surveys were carried out on each individual with sickle-cell anaemia. Since beta-thalassaemia is present in this area (Ismail-Beigi and Haghshenass 1975), only cases are included as sickle-cell anaemiæ in whom haemoglobin studies were available on the parents or other family members to exclude sickle cell beta-thalassaemia.

In all cases the condition was diagnosed by sickle cell preparations followed by haemoglobin electro 0 phoresis. Each individual with sickle-cell anaemiä had a complete physical examination with chest and gall-bladder $x$-rays and bone surveys. Skeletaf changes were graded from 0 to 4+; $1+$ for mild and $4+$ for severe skeletal changes attributable to sickle cell anaemia.

Haematological techniques were followed as:standard methods (Dacie and Lewis, 1968). Blood samples for haemoglobin analysis were collected into acid citrate dextrose solution. Fetal haemoglobin wa determined by the alkali resistance method (Singefo et al., 1951) and its distribution in red cells by the acid elution method (Kleihauer et al., 1957). Re $\$$ cells were examined for sickling using $2 \%$ sodiun bisulphite $\left(\mathrm{Na}_{2} \mathrm{~S}_{2} \mathrm{O}_{4}\right)$ (Dacie and Lewis, 1968): Umbilical cord blood was used for characterization and standardization of fetal haemoglobin analysio and electrophoretic mobility. Known haemoglobin $\mathbf{S}$ was kindly supplied by Dr S. Charache, The Johns 
Hopkins Hospital, Baltimore. The red blood cells of sickle-cell anaemia subjects reported in this study had the characteristic sickling phenomenon and the haemoglobin $\mathrm{S}$ of our patients had the same electrophoretic mobility as the known $\mathrm{Hb} \mathrm{S}$ at several $\mathrm{pH}$ values.

Globin was prepared and the globin chains were separated by chromatography and finger printed, as described by Clegg et al. (1966). Peptide gamma 15 or gamma CB3 was isolated and the glycine/alanine composition was determined as described by Weatherall et al. (1975).

\section{Results}

\section{CLINICAL FINDINGS}

The main clinical and haematological findings are summarized in Tables 1 and 2 . The group with sicklecell anaemia (Table 1) comprised 14 males and 2 females. This disproportionate ratio probably is the result of the higher social mobility of male subjects, many of whom had travelled several hundred kilometers from the Persian Gulf area to Shiraz for referral. In the subjects with homozygous sickle-cell anaemia, the only symptoms which could be attributed to sickle-cell anaemia were mild attacks of musculoskeletal pain which rarely required emergency room visits or admittance to hospital. None of the cases showed disproportion of their body habitus. All had normal fundi. The spleen was palpable in 9 of the subjects and varied up to $6 \mathrm{~cm}$ below the left costal margin. In no case was the spleen tender or nodular. Slight hepatomegaly was noted only in one (case 13) who also had acute hepatitis. Very few presented with pneumonia or other types of infection. There was no evidence of osteomyelitis. Leg ulcers were not noted, and no patients had scars on their legs. Significant skeletal abnormality was found in 1 individual who had aseptic necrosis of the left femoral head (case 9) requiring special surgical treatment. The skeletal surveys were normal in all subjects except in 3 individuals who showed mild osteoporosis without significant trabeculations or sclerosis of the long bones. No splenic opacities were seen. There were no gallstones. Moderate cardiomegaly without congestive heart failure was found in 1 individual (case 9). One female (case 14) had 3 uneventful pregnancies. Two cases of monozygotic twins were also seen (cases 6 and 7). One patient had an attack of priapism (case 15). Urinalysis and blood urea nitrogen were normal in all subjects.

\section{HAEMATOLOGICAL FINDINGS}

Mild to moderate anaemia and raised percentage of reticulocytes was noted in all subjects with sickle-cell anaemia (Table 1). The haemoglobins ranged from

Table 1 Clinical and haematological data in 16 cases of sickle-cell anaemia

\begin{tabular}{|c|c|c|c|c|c|c|c|c|}
\hline Case no. & $\operatorname{Sex}$ & Age $(y)$ & $\begin{array}{l}\text { Splenomegaly* } \\
(\mathrm{cm})\end{array}$ & $\begin{array}{l}\text { Skeletal } \dagger \\
\text { changes }\end{array}$ & $\begin{array}{l}\text { No. of } \ddagger \\
\text { Admissions }\end{array}$ & $H b(g / d l)$ & Reticulocytes & $H b F$ \\
\hline $\begin{array}{l}1 \\
2 \\
3 \\
4 \\
5 \\
6 \\
7 \\
8 \\
9 \\
108 \\
11 \\
12 \\
13 \\
14 \\
15 \\
16 \\
\text { Mean } \pm \text { SEM } \\
\text { Range }\end{array}$ & $\begin{array}{l}\mathbf{M} \\
\mathbf{M} \\
\mathbf{M} \\
\mathbf{M} \\
\mathbf{F} \\
\mathbf{M} \\
\mathbf{M} \\
\mathbf{M} \\
\mathbf{M} \\
\mathbf{M} \\
\mathbf{M} \\
\mathbf{M} \\
\mathbf{M} \\
\mathbf{F} \\
\mathbf{M} \\
\mathbf{M}\end{array}$ & $\begin{array}{r}27 \\
22 \\
18 \\
24 \\
22 \\
3 \\
3 \\
14 \\
19 \\
22 \\
20 \\
5 \\
13 \\
56 \\
12 \\
10 \\
18 \\
3-56\end{array}$ & $\begin{array}{l}6 \\
4 \\
3 \\
0 \\
0 \\
5 \\
4 \\
0 \\
5 \\
0 \\
2 \\
5 \\
6 \\
0 \\
0 \\
0 \\
2 \cdot 5 \\
0-6\end{array}$ & $\begin{array}{l}0 \\
1+ \\
1+ \\
0 \\
0 \\
0 \\
0 \\
0 \\
3+ \\
0 \\
0 \\
0 \\
1+ \\
0 \\
0 \\
0 \\
0.4+ \\
0-3+\end{array}$ & $\begin{array}{l}1 \\
0 \\
0 \\
3 \\
2 \\
0 \\
0 \\
0 \\
2 \\
0 \\
0 \\
0 \\
2 \\
0 \\
1 \\
1 \\
0 \cdot 8 \\
0-3\end{array}$ & $\begin{array}{c}10 \cdot 0 \\
11 \cdot 5 \\
12 \cdot 5 \\
11 \cdot 8 \\
11 \cdot 5 \\
11 \cdot 9 \\
11 \cdot 5 \\
11 \cdot 3 \\
7 \cdot 5 \\
7 \cdot 0 \\
10 \cdot 5 \\
6 \cdot 5 \\
7.1 \\
11 \cdot 1 \\
8 \cdot 1 \\
12 \cdot 1 \\
10 \cdot 1 \pm 0.5 \\
6 \cdot 5-12 \cdot 5\end{array}$ & $\begin{array}{c}5 \cdot 0 \\
6 \cdot 4 \\
18 \\
10 \\
6 \cdot 0 \\
2 \cdot 4 \\
1 \cdot 8 \\
3.5 \\
13 \\
40 \\
15 \\
2.2 \\
22 \\
1 \cdot 0 \\
3 \cdot 4 \\
11 \\
10 \cdot 0 \pm 2 \cdot 4 \\
1.40\end{array}$ & $\begin{array}{l}20 \\
17 \\
12 \\
19 \\
17 \\
38 \\
38 \\
30 \\
9 \cdot 4 \\
20 \\
18 \\
9 \cdot 2 \\
12 \\
94 \\
4 \cdot 9 \\
5 \cdot 8 \\
18 \pm 3 \\
4 \cdot 9 \cdot 38\end{array}$ \\
\hline
\end{tabular}

* Splenomegaly (cm) below the left costal margin.

†Skeletal changes are graded from 0 for none to 4 + for severe skeletal changes.

$\ddagger$ No. of hospital admissions because of musculoskeletal pain.

\$Glucose-6-phosphate dehydrogenase deficient with hepatitis. Reticulocyte count $11 \% 6$ weeks after recovery.

Table 2 Clinical and haematological data in 28 cases of sickle-cell anaemia

\begin{tabular}{lllllll}
\hline No. of cases & Mean age $(y)$ & Male & Female & Hb $(g /$ dl $)$ & Reticulocytes \\
\hline 29 & 34.5 & 14 & 15 & $\begin{array}{l}13.0 \pm 0.3 \\
(9 \text { to } 17)\end{array}$ & $\begin{array}{l}1.4 \pm 0.7 \\
(0.5 \text { to 3.0) }\end{array}$ & $\begin{array}{l}1.6 \pm 0.2 \\
(0.5 \text { to 3.2) }\end{array}$ \\
\hline
\end{tabular}


6.5 to $12.5 \mathrm{~g} / \mathrm{dl}$. Two subjects had conspicuously raised reticulocyte counts $(40 \%$ in case 10 , and $22 \%$ in case 13), while most other subjects had reticulocytes below $15 \%$. The Wright stained smears of peripheral blood in subjects with sickle cell anaemia showed slight to moderate anisocytosis and poikilocytosis with slight to moderate polychromasia; rare spherocytes, ovalocytes, and sickle forms were noted. There was no suggestion of hypochromia. In the sickle-cell anaemia subjects the fetal haemoglobin was distributed in a heterogeneous manner among the red blood cells.

Complete family data were available in all cases except in 4 families in which 1 or both parents had died; in these families data on sibs showed the presence of sickle-cell trait. In the sickle-cell anaemia subjects the mean haemoglobin and reticulocytes were $13.0 \mathrm{~g} / \mathrm{dl}$ and $1.4 \%$, respectively. Twenty-nine cases of sickle-cell trait had detailed haemoglobin analysis. In each case haemoglobin electrophoresis showed $\mathrm{Hb} \mathrm{A}, \mathrm{S}$, and $\mathrm{A}_{2}$. Haemoglobin $\mathrm{A}_{2}$ in this group ranged from 0.5 to $3.0 \%$ and fetal haemoglobin ranged from 0.5 to 3.2 , with a mean of $1 \cdot 6 \pm 0 \cdot 2$. The percentage fetal haemoglobin in our laboratory-tested in 75 healthy individuals-is $0.6 \% \pm 0.2 \%$. Electrophoretic analysis for haemoglobins Barts and $\mathbf{H}$ were done in all cases (Weatherall and Clegg, 1972) and none was found.

STRUCTURAL ANALYSIS

Fingerprinting analysis of the isolated beta chain indicated that this was genuine $\mathrm{Hb} \mathrm{S}$. In 1 case sufficient $\mathrm{Hb} \mathrm{F}$ was present to isolate peptide gamma CB3. The glycine and alanine compositions were determined. The glycine estimation gave a value of 0.85 residues which is in the range found in cord blood samples in this laboratory.

\section{Discussion}

Although sickle-cell anaemia is usually a severe illness, it is becoming apparent that the disorder can also present with a significantly milder phenotype (Sergeant et al., 1968; Ali, 1970; Perrine et al., 1972). This study provides further data on the mild phenotype of sickle-cell anaemia. Many of the subjects reported here had been totally asymptomatic. It is probable that genetic as well as environmental factors play a role in producing such a mild form of sickle-cell anemia. It is interesting that the 18 sicklecell anaemia subjects reported by Perrine $e t$ al. from Arabia were all Shiite Moslems as were our cases. Since the Arabs are predominantly Suni Moslems, the frequency of the disorder in Shiite Arabs probably reflects migration of Persian Gulf populations into the Arabian Penninsula. Though we have not determined the incidence or prevalence of $\mathrm{Hb} \mathrm{S}$ gene in Persian populations, it is clear that the gene is not rare in this area of the world. These findings suggest $\overrightarrow{\vec{s}}$ that there is a gene associated with those for $\mathrm{Hb} \mathrm{S}$ in the Shiite population capable of producing unusually듬 high levels of $\mathrm{Hb} \mathrm{F}$.

Clinical and haematological studies on sickle-cell $\overline{\mathrm{Q}}$ trait subjects revealed that the individuals were asymptomatic and had normal haemoglobin and reticulocyte values. However, the mean fetal haemo- $\overrightarrow{0}$ globin value of this group was significantly higher $-\overrightarrow{-}$ than our normal population $(P<0.005)$. The genetics ${ }_{\sigma}$ of this phenomenon deserve further study.

The most striking difference between our sickle-cellő anaemia subjects and sickle-cell anaemia seen in $\vec{\phi}$ Black populations is the higher percentage of fetaliw haemoglobin present in our subjects $(18 \%)$. The $\vec{\sigma}$ fetal haemoglobin is distributed in a heterogeneous $\infty$ fashion among the red blood cells. The protective effect of $\mathrm{Hb} \mathrm{F}$ against sickling has been well docu- mented (Charache and Conley, 1964; Bertles and $\subseteq$ Milner, 1968). The presence of $\mathrm{Hb} F$ probably $\vec{\Phi}$ decreases the number of cells that can sickle easily $\overrightarrow{0}$ thereby leading to decreased stacking and sludging of $y$ red blood cells in the capillaries. Perrine et al. also. studied the $G_{\alpha} / A_{\alpha}$ ratio of $\mathrm{Hb} F$ in their subjects ando found that the $\mathrm{Hb} \mathrm{F}$ was similar to newborn rather than adult type fetal haemoglobin. This was the case in the 1 sample of $\mathrm{Hb} \mathrm{F}$ studied in this way in the present series. Further data of this type would be of $\cong$ particular interest.

The cause of raised $\mathrm{Hb} F$ value in the subjects 3 studied is not clear. Studies directed towards elucidation of control mechanisms involved in regulation? of $\mathrm{Hb}$ F synthesis in sickle-cell anaemia could be of great scientific and therapeutic value.

The authors are grateful to Miss N. Mohammadi, Mrs F. Tadayon and especially to Mrs P. Sheiko-尺 leslami for their able technical assistance. We would $₹$ also like to thank Mrs. M. Fountaine for her secre-음 tarial help.

\section{References}

Ali, S. A. (1970). Milder variant of sickle-cell disease in A in Kuwait associated with unusually high level of fetal haemoglobin. British Journal of Haematology, 19, 613-619. $\omega$

Bertles, J. F., and Milner, P. F. (1968). Irreversibly sickledo erythrolytes: a consequence of the heterogeneous distribution of haemoglobin types in sickle-cell anemia. Journat? of Clinical Investigation, 47, 1731-1741.

Charache, S., and Conley, C. L. (1964). Rate of sickling of red ${ }^{+}$ cells during deoxygenation of blood from persons with various sickling disorders. Blood, 24, 25-48.

Charache, S., and Richardson, S. M. (1964). Prolonged $\frac{\vec{D}}{(1}$ survival of a patient with sickle-cell anemia. Archives of Internal Medicine, 113, 844-849. 
Clegg, J. B., Naughton, M. A., and Weatherall, D. J. (1966). Abnormal human haemoglobins. Separation and characterisation of the $\alpha$ and $\beta$ chains by chromatography, and the determination of two new variants, $\mathrm{Hb}$ Chesapeake and Hb.J. Bangkok. Journal of Molecular Biology, 19, 91-108.

Coming, E. D. (1972). Sickle cell disease and related disorders. In Haematology, Vol. 1, p. 413. Ed. by J. W. William, E. Beutler, A. J. Ersley, and W. Rundles. McGraw-Hill Book Co., New York.

Dacie, J. V., and Lewis, S. M. (1968). In Practical Haematology, 4th ed. Churchill London.

Ismail-Beigi, F., and Haghshenass, M. (1975). The dependence of the haemoglobin (beta plus gamma)/alpha chain synthetic ratio on the degree of anemia in beta-thalassemia. Proceedings of the Society for Experimental Biology and Medicine 148, 459-462.

Kleihauer, E. F., Braun, H., and Betke, K. (1957). Demonstration von Fetalem haemoglobin in der Erythrocyten eines Blutausstrichs. Klinische Wochenschrift, 35 (2), 637-638.

Perrine, R. P., Brown, M. J., Clegg, J. B., Weatherall, D. J., and May, A. (1972). Benign sickle-cell anaemia. Lancet, 2 , 1163-1167.
Serjeant, G. R., Richards, R., Barbor, P. R. H., and Milner, P. F. (1968). Relatively benign sickle-cell anaemia in 60 patients aged over 30 in the West Indies. British Medical Journal, 3, 86-91.

Singer, K., Chernoff, A. I., and Singer, L. (1951). Studies on abnormal haemoglobins. I. Their demonstration in sicklecell anaemia and other haematologic disorders by means of alkali denaturation. Blood, 6, 413-428.

Weatherall, D. J., Cartner, R., Clegg, J. B., Wood, W. G., Macrae, I. A., and MacKenzie, A. (1975). A form of hereditary persistence of fetal haemoglobin characterised by uneven cellular distribution of haemoglobin $F$ and the production of haemoglobins $\mathbf{A}$ and $\mathbf{A}_{2}$ in homozygotes. British Journal of Haematology, 29, 205-220.

Weatherall, D. J., and Clegg, J. B. (1972). The Thalassemia Syndromes, 2nd ed. Blackwell Scientific Publications, Oxford.

Requests for reprints to Dr M. Haghshenass, Department of Internal Medicine, Pahlavi University Medical School, Shiraz, Iran. 